Ostatni rozdział pracy poświęcono dynamice emocji w trakcie opieki paliatywnej. Autorka, Krystyna de Walden-Gałuszko, reprezentując Wojewódzkie Centrum Onkologii w Gdańsku i mając doświadczenie praktyka, wyodrębnia sytuacje emocjonalne osób chorych onkologicznie: przewidywany kres życia, niepomyślne informacje o rokowaniu, sytuacja choroby, radzenie sobie z sytuacją choroby, okres umierania. Na wszystkich tych etapach podkreślona jest zmienność występujących emocji. „Trzeba jednak pamiętać, że zmiany emocjonalne mogą w tym czasie przebiegać w sposób nieoczekiwany - chory, który świadomie przygotował się do śmierci i zaakceptował ją, w chwili agonii reaguje wybuchem paniki, chory zbuntowany i agresywny lub przygnębiony może mieć chwile przypływu nadziei i optymizmu" (s. 406).

To bardzo cenna książka, warta polecenia zarówno psychologom, neurobiologom, socjologom poszukującym narzędzi badawczych do własnych analiz afektywnych wymiarów życia społecznego, mieć w swej biblioteczce, gdy poszukuje się podpowiedzi na dynamikę własnych emocji w sytuacji stresu, napięć związanych z pracą, chorobą, związkiem czy samotnością. Szczególnie warta jest polecenia w kontekście codziennych zmagań z trudnościami życia rodzinnego: budowania relacji związkowych, przeobrażeń własnej dorosłości, starości, choroby czy dorastających dzieci. Warta jest też polecenia - jak uprzednio wskazano - teoretykom życia rodzinnego zajmujących się rodziną w ujęciu multidyscyplinarnym.

Dariusz Tułowiecki - WNS UPJPII Kraków

\title{
Własność intelektualna wobec wolnego rynku i pluralizmu mediów, red. Dariusz Tułowiecki, Wydawnictwo Uniwersytetu Papieskiego Jana Pawła II w Krakowie, Kraków 2014, 145 s.
}

W czasach współczesnych, w których innowacyjność stanowi klucz do rozwoju, można stwierdzić, że największym majątkiem każdego narodu będą umiejętności jego obywateli. Te umiejętności rozwijane, zagospodarowywane ekonomicznie oraz stanowiące źródło twórczości organizacji - winny podlegać ochronie. Innowacyjność wpisuje się bowiem w pojęcie zasobów ludzkich, obok wiedzy, zdolności, umiejętności, zdrowia, postaw, wartości i motywacjī. Innowacyjność, czyli nowatorska myśl ludzka, może mieć znaczenie praktyczne, użyteczne, wprost

7 Por. W. Harasim, J. Dziwulski, Zarządzanie twórcze, Warszawa 2015, s. 70. 
komercyjne; może być także analizowana w kontekście jej źródła - ludzkiego myślenia ${ }^{8}$. Innowacyjność, zdolność do rozwoju i wszelkie umiejętności nabywane w kontekście osobistym i społecznym, mogą być - jak twierdzi Margaret S. Acher wpisane $\mathrm{w}$,,człowieczeństwo[, które] posiada uprzednie, autonomiczne i zdolne do oddziaływania siły, jakie wnosi do samego społeczeństwa"9.

W czasach wysokiej wagi innowacyjności oraz ochrony ludzkich umiejętności na rynku wydawnictw naukowych ukazała się w Krakowie ważna książka pod redakcją Dariusza Tułowieckiego. Jej celem - w zamyśle redaktora - jest prezentacja dyskursu etycznego nad prawami ochrony własności intelektualnej rozpiętymi pomiędzy wolnym rynkiem a pluralizmem mediów. Dyskurs ten toczy się stale we współczesnym świecie, ilekroć pojawia się problem rozwoju na drodze innowacyjności, przepływu informacji i zarządzania nią, ochrony wytworów pracy intelektualnej oraz poszukiwań napięcia pomiędzy popularyzacją myśli a jej dochodowością. Dyskurs ten rozpięty jest pomiędzy dwoma biegunami. Pierwszy to przekonanie o wadze własności prywatnej, do której należy także własność intelektualna. We Wstępie tak pisze o tym aspekcie Dariusz Tułowiecki: „Istnieje jednak inna forma własności, która szczególnie w naszych czasach nabiera znaczenia nie mniejszego, niż własność ziemi: jest to własność wiedzy, techniki i umiejętności. [...]... właśnie myśl ludzka, i to nawet bardziej niż zasoby naturalne, stanowi współcześnie źródło bogacenia się społeczeństwa, narodów i jednostek. Ta kreatywna praca ludzka [...] składa się na społeczność pracy obejmującą różne kręgi osób. Z pracy i kreatywności jednych korzystają inni: Istnieje zresztą wiele dóbr, których nie można w odpowiedni sposób wytworzyć pracą pojedynczego człowieka i które wymagają zmierzającej do jednego celu współpracy wielu osób. [...] Kreatywność ta [...] jest chroniona, a jej wytwory znajdują się w polu społecznej wymiany podlegającej negocjacjom i szukającej konsensusu" (s. 7).

Drugie stanowisko, to - zbytnie chronienie innowacyjności i wytworów myśli ludzkiej oraz szczelne zabezpieczanie jej jedynie w celu wolnorynkowej sprzedaży i sprowadzanie jej wyłącznie do kategorii zysku, co może rodzić przekonanie, że „ochrona własności intelektualnej nie może mieć charakteru absolutnego, a odstąpienie od niej w pewnych granicach nie tyle zagraża człowiekowi, ile służy jednostkom i społecznościom" (s. 8). Rozpięcie treści niniejszej publikacji pomiędzy tymi dwoma biegunami czyni ją niezwykle ciekawą intelektualnie i wartościową w zbiorze zastosowanych argumentów. Jej celem jest bowiem postawienie ważnych pytań rodzących się w nakreślonym polu oraz próba odpowiedzi. Autorzy poszczególnych artykułów mają świadomość ograniczoności własnych argumentów, ale

8 Por. H. Arendt, Kondycja ludzka, Warszawa 2000, s. 169-185.

9 M. S. Archer, Człowieczeństwo. Problem sprawstwa, Kraków 2013, s. 22. 
też potrzebę stawiania pytań, poszukiwań prawdy i oglądu zagadnienia w interdyscyplinarnej perspektywie badań przemian społecznych. Mają też intelektualną odwagę nakreślić współczesne pole dylematów etycznych związanych z przepływem informacji, zarządzania nimi, komercjalizacji oraz ich poszanowania.

Z niezwykle celną precyzją nakreśla te przestrzenie i pytania redaktor w pierwszej części publikacji: „Zmiany społeczne, zarówno w wymiarze przepływu informacji, rozwoju technologicznego i gospodarczego, jak i przemian stylów życia, rodzą coraz to nowe pytania dotyczące dziedziny ochrony własności intelektualnej, z jednej strony istnieje prawo do ochrony własnej prywatności, z drugiej - trudności z ochroną prywatności osób publicznych, trudności z realizacją prawa do dobrego imienia w świetle półprawd medialnych, wytyczaniem granic ingerencji w sferę życia prywatnego osób publicznych. Z jednej strony mają prawo do ochrony własnych dziel, $\mathrm{z}$ drugiej - istnieje prawo do uczestnictwa w dziedzictwie kulturowym. $Z$ jednej strony istnieje słuszna tendencja do popularyzacji wytworów myśli, z drugiej - rodzi się pytanie, czy twórcy, naukowcy lub kreatorzy intelektualni są w stanie prowadzić godziwe życie za honoraria płacone im przy zakupie ich wytworów intelektualnych? Współczesna gospodarka oparta jest na wiedzy i innowacyjności, ale czy w polskiej rzeczywistości patentowanie pomysłów i zastrzeganie wytworów kreatywności przyjmuje właściwe rozmiary?" (s. 9).

Książka redakcji Dariusza Tułowieckiego jest kompilacją pięciu ważnych tekstów. Ich autorzy to znakomici specjaliści wielu dziedzin, które łączy spojrzenie na nakreślone pole problemowe. Autorzy i ich wypowiedzi zostały trafnie dobrane. Każdy z nich z najwyższym znawstwem przybliża czytelnikowi nakreślony przez siebie zakres tematu. Dzięki interdyscyplinarności publikacji oraz wielości spojrzeń, czytelnik ma możliwość dość szerokiego - jak na rozmiary monografii ujęcia tematyki.

Pierwszy z tekstów to materiał wspólnego autorstwa Izabeli Dobosz i Elżbiety Czarny-Drożdzejko (s. 17-29). Jest on wprowadzeniem w zagadnieniem od strony prawa i merytorycznym umiejscowieniem tematu na polu prawnej ochrony własności intelektualnej. Stanowi on przypomnienie podstawowych pojęć, takich jak: własność intelektualna, prawa autorskie, dobra intelektualne, autorskie prawa majątkowe. Bez tych podstawowych rozróżnień i uściśleń niemożliwe są dalsze, także etyczne, analizy i diagnozy.

Materiał autorstwa Andrzeja Baczyńskiego („Własność intelektualna w mediach - ochrona czy niszczenie kreatywności?”, s. 31-44) to ukazanie kreatywności intelektualnej i dostępu do niej w warunkach globalizacji. Kreatywność zabezpieczona prawem własności przemysłowej, prawami autorskimi, jak i pokrewnymi, jest fundamentem współczesnych gospodarek, w tym sektora informacyjnego. Autor - dziennikarz i specjalista od teorii komunikacji - wskazuje zarówno Internet 
jako kanał obiegu kultury, jak i prawa ochrony własności jako czynnik chroniący, ale też ograniczający przepustowość tego narzędzia komunikacji. Poszukuje on także nowych rozwiązań w niwelowaniu współczesnego napięcia pomiędzy własnością a wolnością w mediach.

Cenny dla publikacji jest tekst Andrzeja Zwolińskiego „Wszystko na sprzedaż” (s. 45-77). Autor potrafiący prowokować nie tylko tytułem swych publikacji wskazał, w jaki sposób zróżnicowanie i przemiany kanałów komunikacyjnych utworzyły nowe typy relacji społecznych. W relacjach tych doszło i wciąż dochodzi do nowych zagrożeń: cyberkontroli, cyberanarchii i infokracji. Sieci informacyjne stają się narzędziem kontroli oraz przejmowania władzy nad jednostkami i społecznościami. Sieci te także przyjmować mogą postać urynkowionej, nastawionej na maksymalizację zysku, sieci sprzedaży danych, także intymnych, przestrzeni usług i handlu. „Najbardziej spektakularna sprzedaż swej intymności dokonuje się poprzez zamieszczanie różnego rodzaju danych o sobie samym w Internecie. Najczęściej potencjalna ofiara jawności nie ma świadomości, że dane, które zamieszcza na różnych stronach Internetu identyfikują ją i czynią przejrzystą w różnych okolicznościach życia publicznego. Samoujawnienie dokonuje się więc w sposób nieświadomy, mimochodem, jakby na marginesie ogólnej euforii z powodu korzystania z bliskości i powszechności dostępu, który gwarantuje Internet” (s. 55).

Autor, jako wytrawny akademik zajmujący się myślą społeczną Kościoła, swą wypowiedź kończy wskazaniem przestrzeni ryzyka i zagrożeń społecznych związanych z wymianą z siecią. „Przejawem bezprawia w sferze Internetu i dysponowania zebranymi danymi jest kradzież skrzętnie kompletowanej informacji. Ma ona miejsce na ogromną skalę w szpiegostwie sieciowym. Ofiarami przestępców stały się już instytucje państwowe - agencje rządowe, ambasady, instytucje zaangażowane $w$ badanie energii atomowej, przedsiębiorstwa poszukujące ropy naftowej i gazu, firmy przemysłu lotniczego [...]" (s.70). Zwoliński szuka także odpowiedzi na pytania o racje i uwarunkowania społeczne życia w sieci, w tym - izolację od świata realnego a komercjalizację lub działania przestępcze w przestrzeni wirtualnej.

Na szczególne wyróżnienie zasługuje w książce arcyważny tekst Jacka Sobczaka: „W poszukiwaniu nowego modelu dziennikarstwa. Między wymogami prawa, nakazami etyki a oczekiwaniami rynku" (s. 79-118). Ten wybitny prawnik, sędzia Sądu Najwyższego i znawca tematu mediów, nakreśla wymagania zawodu i warsztatu dziennikarskiego, przemian świata, w tym świata przepływu i kształtu informacji medialnych, dylematów zawodu dziennikarza. Wskazuje także głębokie przemiany zachodzące w pracy dziennikarskiej, które w sposób konstytutywny zmieniają tożsamość pracowników mediów. „Dziennikarz w coraz mniejszym stopniu jest obecnie przewodnikiem po skomplikowanym świecie: kompletnym 
i cierpliwym tłumaczem rzeczywistości politycznej, gospodarczej i społecznej; mądrym doradcą w sprawach życia codziennego; nauczycielem konsekwentnie, niestrudzenie, wytrwale wskazującym swojemu czytelnikowi drogi wyboru. Coraz rzadziej jest on podobny do pisarza lub artysty. Coraz częściej jawi się on jako pracownik mediów (media worker), skrzętnie wypełniający polecenia zwierzchników, sprawny wykonawca ich woli, człowiek kompetentny, któremu jednak obojętne są względy natury etycznej, gotów do podjęcia się zadań najbardziej podłych i nieetycznych, byleby tylko zasłużyć na uznanie pracodawcy i zdobyć lepszą pozycję w środowisku" (s. 84).

Autor stawia wartą zauważenia tezę, że kodeksy etyki dziennikarskiej nie spełniają swej roli. Z racji na swą zbytnią ogólnikowość oraz mało konkretny charakter, przy niskich wskaźnikach tych „kart mediów”, nie tyle chronią twórców mediów przed nieufnością odbiorców, co jedynie stanowią narzędzie autouwiarygodniające środowiska medialne. Ta promocja swego wysokiego etosu zawężona oddziaływaniem do własnego środowiska nie chroni jednak dziennikarzy przed autentycznymi trudnościami etycznymi ani nie wskazuje rozwiązań realnych problemów. „Wskazuje się, że permanentne niedochowywanie standardów etycznych przez dziennikarzy pozwala na sformowanie wniosków, że kodeksy etyki służą dziennikarzom przede wszystkim do promowania własnego środowiska, kreowanie obrazu prasy na zewnątrz, a nie na regulacji zachowań dziennikarskich" (s. 90-91).

Jacek Sobczak trafnie umiejscawia i wyszczególnia przestrzenie dylematów etycznych: profesjonalizacja zawodowa, wysoka specjalizacja, zespołowość pracy, zanik granicy pomiędzy informowaniem a komentowaniem, dbałość o formę kosztem treści, nadmierna troska o sprostanie wymaganiom odbiorców. Z najwyższym znawstwem ukazuje także zawód dziennikarza w kontekście zapisów prawa i orzecznictwa. Nakreśla również kierunki dalszych przemian rynku medialnego oraz roli środowiska dziennikarskiego w zmieniającej się rzeczywistości mediów. Tekst Jacka Sobczaka cechuje najwyższy poziom znawstwa tematu, jakość i ilość przywoływanej literatury wskazuje na wybitną orientację autora, jasność zaś prezentacji - na wyjątkową umiejętność prezentacji myśli wypracowanej na drodze łączenia wykładu akademickiego z wyczuciem rzeczywistości przez praktyka.

Publikację zamyka wypowiedź Pawła Prüfera: „Rzemiosło intelektualne i refleksyjność. Trud i efekty pracy badacza społecznego intelektualną własnością prywatną czy instrumentem użyteczności społecznej?” (s. 119-145). Autor, będąc socjologiem oraz znawcą myśli społecznej Kościoła, sytuuje pracę naukowca jako składnik dobra wspólnego. Praca badacza naukowego jest - według Prüfera - specyficznym rodzajem aktywności człowieka, którą realizuje ze względu na innych i ze względu na samego siebie. Refleksyjność, a zwłaszcza socjologia refleksyjna, dostarczają cennych narzędzi dla spojrzenia na ten rodzaj aktywności ludzkiej. 
Badacz społeczny zastanawia się nad sensem swojego trudu. Zarówno siła myśli ludzkiej, jak i aktywności użytecznej społecznie, są dwiema stronami tego, co uznaje się za rzemiosło intelektualne. „Istotą refleksyjności jest kontemplacja i refleksja. Oznacza to, iż w działalności naukowej liczy się nie tylko aktywność o charakterze badawczym, racjonalnie zaplanowana i przygotowana, stosowana z poszanowaniem reguł metody naukowej. W każdym razie taki namysł, jego jakość, wpływają także na siłę i moc jego użyteczności społecznej” (s. 131-132).

Zasady katolickiej nauki społecznej - wedle Prüfera - porządkują kwestię pracy badacza społecznego. Aktywność naukowca dokonującego pomiarów i analiz jest formą spłaty długu względem społeczeństwa. Naukowiec bowiem zaciąga swoisty dług względem społeczeństwa, wysiłek badawczy zaś oraz refleksyjność na poziomie akademickim jest formą spłaty tego zadłużenia poprzez innowacyjny wkład intelektualny w życie społeczne: ,[...] efekty badań społecznych i prowadzonej refleksji mogą i powinny przynosić konkretne, wymierne i skuteczne korzyści o charakterze społecznym [...]" (s. 132).

Refleksyjność socjologiczna i etyczna sprzyja wypracowaniu wspólnej metody i drogi wspierania społeczeństwa i człowieka w jego rozwoju. Wysiłek intelektualny akademików, owa usystematyzowana refleksyjność i systemowa kontemplacja rzeczywistości, ma wyjątkowe znamiona użyteczności społecznej. Użyteczność ta nie oznacza automatycznej i płytkiej pragmatyczności, komercjalizacji czy wprost maksymalizacji zysków ekonomicznych. „Wydaje się logiczne, że każdy rzemieślnik - w dosłownym tego słowa znaczeniu - czyni swoje wytwory po to, aby były przydatne. Nawet gdyby miały one stanowić jedynie przedmiot estetycznego zachwytu, to także i wtedy można byłoby mówić o ich użyteczności. Przydatność należy także rozumieć, jako humanizację świata społecznego, wydobycie jednostki ze społecznego chaosu i dostrzeżenie w nim człowieka" (s. 135).

Konkluzję tekstu stanowi wyjątkowo cenna próba nakreślenia przesłania adresowanego do badaczy społecznych - do rzemieślników intelektualnych. Ma ono za cel wspomożenie w budowie etosu badawczy akademików oraz waloryzację trudu pracy, którą na co dzień podejmują.

Publikacja „Własność intelektualna wobec wolnego rynku i pluralizmu mediów” jest cennym pokłosiem dyskusji, jaka odbywa się w środowisku prawniczym, dziennikarskim, przedstawicieli nauk społecznych, ekonomistów i etyków. Dyskurs ten ogniskuje się na prawnym opisie oraz etycznych aspektach ochrony własności intelektualnej, mechanizmów wolnego rynku z własnością tą związanych oraz pluralizmem mediów. Książka jest głosem polskiego środowiska akademików zajmujących się myślą społeczną Kościoła, którzy w jej świetle poszukują oceny i rozwiązań problemów prawnych, społecznych oraz ekonomicznych. Jest to publikacja wartościowa i cenna, warta zauważenia i lektury zarówno dla prawników, 
ekonomistów, medioznawców, etyków, jak i tych, którzy samodzielnie zastanawiają się nad mechanizmami świata oraz etyczną ich oceną.

Wiesław Harasim - WSP Warszawa

Sprawozdanie z Międzynarodowej Konferencji Naukowej pt. „Wsparcie rodziny w obszarze pomocy społecznej jako zadanie i powinność", Uniwersytet Kardynała Stefana Wyszyńskiego w Warszawie, 18 listopada 2015 roku.

W dniu 18 listopada 2015 roku w Uniwersytecie Kardynała Stefana Wyszyńskiego odbyła się Międzynarodowa Konferencja Naukowa pt. „Wsparcie rodziny w obszarze pomocy społecznej" zorganizowana przez Wydział Studiów nad Rodziną UKSW we współpracy z Instytutem Papieża Jana Pawła II w Warszawie. Konferencja miała charakter interdyscyplinarny. Prelegenci z kilku ośrodków naukowych z Polski, Litwy i Niemiec reprezentujący różne dziedziny naukowe podejmowali problematykę wspierania i pomocy rodziny z różnych perspektyw: pedagogicznej, socjologicznej, pracy socjalnej, politologicznej i teologicznej.

Prof. UKSW dr hab. Anna Fidelus (Wydział Nauk Pedagogicznych UKSW) wygłosiła referat „Relacyjny model pracy z rodziną dysfunkcyjną (założenia i praktyka)", w którym zaprezentowała założenia relacyjnego modelu pracy z rodziną opartego na samoświadomości. Wskazała, że umiejętność samopoznania rodziny, poznania samego siebie przez członków rodziny jest ważnym elementem w życiu każdego człowieka, a zwłaszcza w odniesieniu do rodziny dysfunkcyjnej. Patrząc na założenia tej teorii z perspektywy pracy z rodziną, dostrzegamy konieczność wykorzystania metody pracy pozwalającej na rozwój umiejętności związanej ze znajomością samego siebie. Poszukując adekwatnego sposobu pracy w tym obszarze, można skorzystać np. z metody dialogu motywująco-wspierającego. Prelegentka podkreśliła, że $\mathrm{w}$ działaniach wspierających rodziny z problemami zasadnym wydaje się korzystanie z założeń podejścia społeczno-przestrzennego. Rozumienie przestrzeni społecznej z perspektywy idei relacjonizmu wyznacza określone postępowanie dla praktyki socjalnej zmierzającej do efektywnej pomocy poszczególnym rodzinom.

Kolejny referat pt. „Polityka rodzinna w programach i praktyce działania polskich partii politycznych w latach 2005-2015" przedstawił dr Bartłomiej Biskup (Instytut Nauk Politycznych, UW). Zaprezentowane zostały przedsięwzięcia głównych polskich partii politycznych na rzecz wspierania rodziny w okresie ostatnich dziesięciu lat. Zwrócono uwagę na kierunki polityki rodzinnej poszczególnych 